\section{Speaking Truth to Bureaucratic Power: Three National Re- sponses to Cholera}

\author{
by Stephen Turner, University of South \\ Florida
}

The State delegates its executive authority to civil servants, or bureaucracies, and delegates much of the "discussion" leading up to decisions to advisory bodies of various kinds. But there are strong national differences in the patterns of delegation, particularly in relation to expert knowledge. The article examines three major traditions in the light of one revealing example: the problem of cholera in the nineteenth century. It also considers the problem of expert knowledge in relation to claims made by Ulrich Beck $(1992,1994,1995,1997)$ to the effect that some form of popular participation is an appropriate corrective to expert opinion.

\section{Cholera and Experts}

In recent writings regarding cholera in the nineteenth century, scholars have increasingly made clear the extent to which the "right" experts were ignored, the distinctiveness and contingency of the situations which they were in, and the extent to which politics, especially bureaucratic politics, played a significant role in both the failed reception of new ideas about cholera failure to implement the necessary measures, particularly the creation of sanitation processes and water filtration. The story of the Hamburg epidemic of 1892 is emblematic of expertise gone wrong. The reaction of the London St. James Parish Board, which was persuaded to remove the handle of the Broad Street pump by a commission that included John Snow, is emblematic of right decision making. The actions of the sanitary commission of the city of New York also stand out as a success. The actions in Britain of the General Health Board, which operated with a bad theory of cholera that was only slowly abandoned, is an example of partial success. London was spared an epidemic like Hamburg's as a result of their efforts.

Richard Evans's classic text on the Hamburg cholera epidemic of 1892 comes to the following conclusion:
Hamburg experienced a major cholera epidemic in 1892 for three basic reasons. Last in order of importance, and coming into operation only when the other two factors had their effect, was the chronic overcrowding, poverty, and malnutrition which ... existed in virtually all the poorer areas of the city, above all after the new harbor construction of the 1880s. This acted as a "multiplier" of the disease by facilitating its rapid spread from person to person. It could only come into action because the disease was carried to virtually every household in the city by mains water. The failure of the Senate and the Citizens' Assembly to agree on a proper filtration system for the water-supply until it was too late, and the failure to implement a comprehensive system of sewage disposal and treatment, must be accounted the principal reasons for the epidemic proportions reached by the disease ... Most important of all was the Hamburg authorities' policy of concealment and delay. (Evans 1987, p. 304)

This is a good point to begin the comparisons, because this was a case in which expert knowledge - science - was catastrophically misgoverned.

The misrule in Hamburg occurred through a combination of the inability of "public dialogue between the broadest variety of agents" to use Beck's phrase - to reach agreement, and a powerful official bureaucratic apparatus able to keep secrets. So we may take it as a test of a certain model of governance of science: one in which powerful bureaucracies are directed and controlled by public discussions which are themselves governed by elaborate procedures. The alternatives to this model are those in which intermediate bodies operate to provide facts or conclusions that can be made the subject of public discussion and action.

In Hamburg there had been, prior to the epidemic of 1892, a long political discussion over the problem of drinking water, of precisely the inconclusive kind that Beck supposes should be an expected outcome of what we may call, for want of a standard label, "expert-egalitarian” discussion, by which we may mean "discussions in which everyone is treated as undifferentiated with respect to their expertise”. A political decision for filtration and clean water, which, according to the theories accepted elsewhere, was essential to avoid cholera being spread through the water supply, would have been costly. It was 
blocked through disagreement over how to charge for it, as well as because of skepticism about the need. The popular opinion was that the available river water was especially pure, and this was an important reason for the failure of the political discussion to produce agreement. Yet the Hamburg politicians did consider expert advice from their local bureaucrats and the local medical community: the two were closely entwined, and both groups supported a theory of cholera derived from Max von Pettenkoffer's view of cholera (Evans 1987, pp. 194-7, 199200), which minimized the problem of transmission through water of the cholera bacterium. Pettenkoffer, a Munich physician, held the view that the cholera bacterium alone could not produce the disease. In a famous demonstration, he drank a beaker of infected water, to no ill effect. He thought the disease required other conditions, including "fermentation" in the ground, which implied different public health measures.

The board acted in accordance with a process in which they were constrained not by the views of other experts, which might have forced them to consider alternatives to their own view, but were directly controlled only by the Hamburg senate and lower house, that is to say by politicians and notables who provided the sole form of official public discussion. Hamburg also had commissions. But public discussion in these commissions conformed rather closely to Beck's ideal: the commission was ignored (Evans 1987, p. 158). There was no delegation of decisionmaking power to expert bodies, no "monopolization," which is what Beck in principle rejects. Delay and non-decision were the consequence.

\section{Where Bureaucratic Expertise Fails}

The inadequacy of the advice of the Hamburg medical community reflects a more general phenomenon. One of the features of bureaucracies is that career advancement is heavily dependent on conformity. Strong bureaucracies penetrate into the professional or expert community, affecting the climate of opinion within them. The effect of a powerful bureaucracy in this case was to assure conformity with what turned out to be a mistaken theory of cholera. But powerful bureaucracies of this sort succeeded elsewhere. In Berlin, the same kind of bureaucratic power produced conformity with what turned out to be the right view, and Berlin was spared. But Koch's powers, as described by Evans, are the fullest realization of the intertwining of bureaucratic power and control of opinion through the control of careers:

\section{Koch could ... be assured ... of vigorous back- ing from the Imperial government in imposing his views on cholera prevention on medical authority throughout the Empire. Already in June 1884 he was made a member of the Prussian Privy Council (Staatsrat) and co- opted onto the Cholera Commission for the German Empire. This had hitherto been con- trolled by Pettenkoffer. Koch became the dominant force. In the same year he organized a course of the diagnosis and prevention of cholera, in which 146 doctors took part, in- cluding 97 civilian (i.e., nonmilitary) doctors from all parts of Germany and 20 other coun- tries. In 1885 he became full professor (Ordi- narius) of Hygiene at the University of Berlin, and was appointed Director of a specially cre- ated institute for Infectious Diseases in 1891. These positions enabled him to influence large numbers of pupils in favor of his ideas and methods. His influence was further spread by his senior pupils. ... Koch founded a journal for the propagation of his ideas, the Zeitschrift für Infektionskrankheiten. Thus Koch and his pupils were rapidly taking over the field of hygiene (Evans 1987, pp. 266-67).}

So the expert advice which the politicians dealt with in each case was essentially monolithic, but different. The expert with authority in Berlin was Koch. But Koch had no direct authority over Hamburg, whose physicians were influenced by Pettenkoffer.

\section{Multiple Sources of Expertise}

If we consider two other cases with different structures, the results are revealing. In London, there was a national bureaucracy, the General Health Board, headed by a statistician and sanitary reformer named William Farr. Farr was wrong about cholera - he was a miasmatist, who had produced an impressive curve fit to data on cholera deaths in London, which he published, based on the idea that elevation decreased the number of cholera deaths in an epidemic. He also produced a vast quantity of research relating to other variables, especially social variables, water quality and so forth, none of which 
produced the startling consistency of the elevation data. The bureaucracy headed by Farr was never powerful as a regulatory body. Decisions about water, for example, were local. Moreover, the career structure of London medicine was such that no bureaucracy had much ability to assure the conformity of the local medical community. Farr's office had a monopoly on the official publications it produced about cholera, but these were not binding on local authorities. Nor was there any particular career benefit to conformity to the position of the General Health Office. And this led to a different outcome.

Beginning with the political achievement, which is only now being acknowledged, of the St. James Parish committee which was persuaded to remove the handle of the Broad Street pump - now one of the most celebrated episodes in the history of medicine (Brody et al 1999). The means by which this political act occurred are partly known. The parish committee, faced with a local outbreak of cholera, what we would now call a "cluster," appointed Snow and a clergyman named Henry Whitehead to a special cholera inquiry committee to deal with an outbreak of cholera near Golden Square. He applied the spot map technique, and found that 73 of the 83 cases were near the Broad Street pump, which Snow reasoned was the source. Whitehead was skeptical of this explanation at first, but was soon convinced. Some who drank the water escaped cholera, others who didn't drink it contracted the disease. But the proportions were overwhelmingly in support of the pump hypothesis.

The parish committee asked Snow to write the report up, and Whitehead himself figured out what had contaminated the pump water - a leaky cesspool three feet from the pump. The material came from the washing of the diapers of an infant who had died and for whom the cause of death was listed as diarrhea. The discovery led the parish committee to excavate the pump area, which revealed that the brick linings of both the well and the cesspool had decayed, allowing seepage. The pump's handle was removed, and the outbreak subsided. This was an act of a small political body faced with an emergency, but in a position to create its own commission, listen to its conclusions, and act independently on them - or decline to act.
This dramatic episode was only a small part of the story, however. Snow's own efforts began long before this episode, and the absorption of his views continued long after. The medical background was complex. Cholera was the most researched disease of the century, and many correlations, as well as many well-attested cases, were part of its large literature. Snow, a private physician, was struck by the many remarkable cases in which cholera spread over vast distances, apparently carried by individuals, strange cases in which cholera attacked one group, such as the passengers of a particular ship, and spared those that had left from the same port at the same time, and cases where one company of soldiers passing a water hole and drinking from it left healthy, and the next one became deathly ill. These cases were difficult to square with any sort of miasmatic or "fermentation" account.

Snow hypothesized, as it turned out correctly, that the real cause was minute material in the evacuations of the victims, that got into the water supply or was otherwise ingested. In an era in which proportionality of cause and effect was a standard methodological rule, and before the microbe account of disease was accepted, this was a radical idea. It was also easy to regard it not as radical, but as old news. Even Farr's research office agreed in some respects with the basic idea: bad water was one of the many variables they found to be associated with cholera. But bad water was badly defined, and not defined in a way that was readily amenable to policies that allowed epidemics to be stopped or prevented. In the long run, this was the loophole through which the bureaucracy grudgingly accepted Snow's arguments - as though they had been theirs all along. But it was an important loophole, for it allowed for the institution of reforms that had the desired result.

Snow's hypothesis was startlingly reconfirmed as a result of a natural experiment in which a mysterious outbreak of cholera occurred after changes had been made in the water supply, but only among the customers of one water company. This appeared to refute Snow. It was then discovered that the company had been illegally drawing water from a source that was "impure." What is striking about this story is, on the one hand, the obduracy of the bureaucratic experts, though they did eventually concede that Snow was right, and on the other the ability of 
Snow - and the motivation - to persuade the parish committee, which promptly created a "commission" rather than attempting to make the decision on its own, to act on his ideas, and the openness of the committee to being persuaded. The result was that London did not have another cholera epidemic after the changes in the water supply were fully put into effect.

\section{Private Expertise: the American Case}

The American version of this story is equally interesting, largely because it represents a different combination of politics, expertise, and bureaucratic structures. In the United States, public health matters in the nineteenth century were for the most part controlled by municipalities, which were, in the case of New York and other major cities, democratic in a particular sense - dominated by the "spoils system". The major device for dealing with the threat of cholera was sanitation, and sanitation contracts were political plums. Boards of Health, in a typical arrangement that applies to many boards even today, were composed of elected officials who were stakeholders of various kinds who sat as the board of health and used its special powers when circumstances required. The politicians Democrats, in this case - preferred to conduct business as usual. But they were vulnerable to reformers, and in the manner that they were defeated the deep roots of national political and bureaucratic traditions become visible.

Tocqueville, writing a few decades before, had observed that "a single Englishman will often carry through some great undertaking, whereas Americans form associations for no matter how small a matter. Clearly the former regard association as a powerful means of action, but the latter seem to think of it as the only one” ([1835]1966, p. 514). This is precisely how cholera was attacked. As Charles Rosenberg notes in his history of the American response to cholera (1962), "it is hardly surprising that New York's Citizens' Association (an informal group of respectable - and predominantly Republican - Gothamites organized early in the 1860's to promote 'honest government') should sponsor a subsidiary Council of Hygiene and Public Health" (p. 187). This "council" - a case of a Tocquevillian association - surveyed the sanitation arrangements of the city, and re- ported the dismal results of the sanitary regime in place. Another arm of the Citizens' Council was at work on reforming the political structure that produced it, proposing a bill in the state legislature to create a board of health that did not operate on the spoils system, and had experts rather than politicians on it. This was a lesson drawn from the examples of Paris and London, but also from Providence, Rhode Island and Philadelphia. The bill required that the board consists of medical men trained especially for public health work (Rosenberg 1962, pp. 188-91).

The state of knowledge in 1866 was expressed by the New York Academy of Medicine, yet another Tocquevillian association which advised the medical profession to "for all practical purposes, act and advise in accordance with the hypothesis (or the fact) that the cholera diarrhoea and 'rice-water discharges' of cholera patients are capable in connection with wellknown localizing conditions, of propagating the cholera poison, and that rigidly enforced precautions should be taken in every case to disinfect or destroy these ejected fluids" (quoted in Rosenberg 1962, p. 195). The resolution reflected some medical politicking - the "local conditions" clause assured unanimity, though few doubted that the discharges alone were the cause. But it also reflected the internationalization of expertise on the topic, and the rapidity of "conversions" to the "Snow-Pettenkoffer" account of the disease, which in practice was the Snow account, was impressive.

The New York Sanitary Commission, which had been granted enormous power by the legislature, acted accordingly: “... the bedding, pillows, old clothing, and utensils - anything that might 'retain or transmit evacuations of the patient' - were piled in an open area and burned" (Rosenberg 1962, p. 205). New York City escaped cholera, other states copied the legislation (Rosenberg 1962, p. 211), and the contained "epidemic" of 1866 was the last serious cholera threat in the United States. The politics of opposition are worth noting, especially in light of Beck's demands. The Commission was imposed by the state legislature, which was dominated by Republicans; the Democrats, Catholics, and immigrants of New York City opposed it as the creation of rural 
lawyers that favored the rich at their expense (Rosenberg 1962, p. 208).

The New York Sanitary Commission was composed of experts, but experts who were experts as private individuals rather than individuals who were the creation of a consensus producing career structure in a powerful bureaucracy. They were accountable professionally but also accountable as public figures for their actions, in the sense that their personal and professional reputations were closely tied to the outcomes of what were very public decisions. And there were associations, such as the Citizens' Council and the New York Academy of Medicine, which were independent watchdogs, with an eye on the practices of other governments and on international expertise. A member of such a board was highly constrained by these bodies - someone who did not wish to jeopardize a carefully built-up reputation both as an individual and as an expert would be obliged to resign or to protest bad decisions.

\section{Expert Egalitarianism}

Beck's model contrasts with this rather sharply, because in a situation of expert egalitarianism, reputation is unimportant or equalized, as is responsibility for the outcome: rather than being held responsible, a person can behave irresponsibly without consequences or act in terms of self-interest without consequences. Indeed, this is a major part of the Hamburg story. The issue of taxation which was entirely a matter of interest politics prevented the reaching of a resolution, exactly as Beck says is a permissible outcome, with the consequence that filtration devices were not built until after the epidemic had taught the public lesson that they were necessary. To be sure, if Hamburg had been as fortunate as Berlin to have had the right leading figures in its bureaucracy, bureaucratic power and the consensus it favored would have produced the right decision. But the issue of "governance" is not eliminated by the existence of powerful bureaucracies. Someone needs to pick the powerful bureaucrats and to judge the bureaucracy. The Hamburg notables and politicians, who were closely related to the medical community, proved incapable of doing so. Thus the combination of interest group democracy and powerful bureaucracy is more generally prone to the same very particular kind of error, and in this case it proved fatal.

\section{Using Expertise Effectively}

Germany had the best science at the time of the Hamburg epidemic - Koch had won a Nobel Prize for identifying the cholera bacterium. Yet it had the worst cholera epidemic of Europe, long after other countries had solved their cholera problem. Is it too much to compare this to the situation in German physics during WWII? There again, Germany had the best scientist, Heisenberg, and the best intellectual resource base. The customary view of this episode is that authoritarianism led to failure. Heisenberg, uncorrected by vigorous debate from his subordinates, made a key error and failed to see the solution to the problem of fusion. But in a larger perspective, the problem may be seen to be one of the organization of scientific activity: The bureaucratic structure of the research effort led, as it led in the Hamburg medical community, to a consensus that turned out to be false. And it is difficult to imagine a powerfully bureaucratic mode of the governance of science that would not be systematically prone to this kind of error.

James Bryant Conant, the last High Commissioner of Germany and the first American Ambassador to West Germany, writing after the Second World War, described the following model for presenting expert opinions to decision-making bodies. To avoid what he took to be the central problem of scientists promoting their own hobby horses, he suggested that even a good idea ought to be able to withstand criticism and proposed that opponents be selected to play the role of devil's advocate. These opponents would argue for alternative proposals so that decision-makers would be given a genuine choice, but also so that the experts would be forced to articulate arguments that would be not merely persuasive to nonexperts but tested against the criticisms of the expert opponent. This left judging in the hands of nonexperts, but gave experts their due as pleaders of cases. There is a sense in which this model is the one that most closely represents the situation in St. James Parish, and in the body that the parish committee created when it joined Snow with a skeptical clergyman. Snow obviously was arguing not only a minority 
view but a view opposed by the official bureaucracy. Snow nevertheless prevailed, producing perhaps the single best decision in the whole cholera affair.

The New York model is also revealing: expertise constrained by expert scrutiny, in a situation in which the "outside" experts are genuinely independent, and in which the reputations of the experts exercising authority are, in effect, marketized, so that they would suffer for their obduracy, constrains experts very effectively, while at the same time producing decisive results- the New York methods were highly effective and easy to imitate. Whether this is a model that can be used in other political traditions, such as the German, in which "cooperation" is the working norm, is open to question. In each of the cases some other means of protection against the error-prone combination of bureaucratic power and the quasi-scientific "consensus of scientists" existed. And this is something that powerful bureaucracies which create their own climates of opinion effectively preclude.

\section{References}

Beck, U., 1992: The Risk Society: Towards a new modernity. London, Newbury Park, Cal.: Sage Publications

Beck, U., 1994: The reinvention of politics: Towards a theory of reflexive modernization. In: Beck, U.; Giddens, A.; Lash, S. (eds.): Reflexive Modernization. Stanford, Cal.: Stanford University Press, pp. 1-55

Beck, U., 1995: Ecological Enlightenment: Essays on the Politics of the Risk Society. M. Ritter (trans.). Atlantic Highlands, N.J.: Humanities Press International, Inc.

Beck, U., 1997: Erfindung des Politischen: The Reinvention of Politics: Rethinking Modernity in the Global Social Order. Mark Ritter (trans.). Cambridge: Polity Press; Cambridge, Mass.: Blackwell Publishers

Brody, H; Vinten-Johansen, P.; Paneth, N.; Rip, M.R., 1999: John Snow revisited: Getting a handle on the Broad Street pump. Pharos 62(1), pp. 2-8

Conant, J., 1951: Science and Common Sense. New Haven, CT: Yale University Press

Evans, R.J., 1987: Death in Hamburg: Society and Politics in the Cholera Years 1830-1910. Oxford: Clarendon Press
Rosenberg, Ch.E., 1962: The Cholera Years: The United States in 1832, 1849, and 1866. Chicago: The University of Chicago Press

Tocqueville, A. de, [1835]1966: Democracy in America. ed. J. P. Mayer, trans. George Lawrence. Garden City, NY: Doubleday \& Company, Inc.

\section{Contact}

Stephen Turner

Graduate Research Professor of Philosophy

Department of Philosophy FAO 226

University of South Florida

Tampa, FL 33620, USA

Tel.: +1 - 813 - 974- 5549

Fax: +1 - 813 - 974 - 5914

E-Mail: turner@shell.cas.usf.edu 